\title{
Optimization of the Cultivation of Donor Mesenchymal Stromal Cells for Clinical Use in Cellular Therapy
}

\author{
Vanessa Valim1,2, Bruna Amorin1,2, Annelise Pezzi1,2, Maria Aparecida Lima da Silva1,2, \\ Ana Paula Alegretti ${ }^{1,2}$, Lucia Silla ${ }^{1,2,3}$ \\ ${ }^{1}$ Cellular Therapy Center, Hospital de Clinicas de Porto Alegre, Porto Alegre, Brazil \\ ${ }^{2}$ Post-Graduation in Medicine: Medical Sciences, Federal University of Rio Grande do Sul, Porto Alegre, Brazil \\ ${ }^{3}$ Hematology and Bone Marrow Transplantation, Hospital de Clinicas de Porto Alegre, Porto Alegre, Brazil \\ Email: Isilla@hcpa.ufrgs.br
}

Received 11 January 2014; revised 11 February 2014; accepted 18 February 2014

Copyright (C) 2014 by authors and Scientific Research Publishing Inc.

This work is licensed under the Creative Commons Attribution International License (CC BY). http://creativecommons.org/licenses/by/4.0/

(c) (i) Open Access

\begin{abstract}
Mesenchymal stromal cells (MSC) have shown their benefits in graft-versus-host disease (GVHD), with five unsettled matters: 1) MSCs expansion in medium with Fetal Bovine Serum (FBS) and its risk of xenoreaction; 2) The number of cells indicated for therapy that is relatively high, with the need to optimize the expansion, number and time wise; 3 ) The utilization of third party donors; 4) Culture passage number (P); and 5) Source of the cells. This study was designed to determine the superiority of the Platelet Lysates (PL) over FBS on the expansion of MSC, the optimal cell' plating density and days between each pass, and to investigate if donor total nucleated cells (TNC) obtained from the washouts of discharged bags and filters of hematopoietic stem cell transplantation (HSCT) can be expanded to be used at clinical grade. TNC were removed, plated and after the first passage were cultivated in different concentrations with FBS or PL, and the number of days to reach $80 \%$ of confluence was observed. Next, cultures with the same plating density were fed either with PL or with FBS and after seven days counted to analyze how much they had grown in that period. The proliferation of mesenchymal stromal cells in the presence of PL and SFB was averaged 11.88 and 2.5 times, respectively, in a period of 7 days. The highest concentration of plating cells using PL took less time to reach confluence as compared with the three lower ones. This study suggests that the PL is the best choice as a supplement to expand MSC and to allow the proliferation of enough number of MSC at P2 for clinical use.
\end{abstract}

\section{Keywords}

Platelet Lysate; MSC, Optimization; Cell Therapy 


\section{Introduction}

Mesenchymal stem cells (MSCs), also referred to mesenchymal stromal cells, are considered as non-hematopoietic multipotent stem cells with self-renewal properties and ability to differentiate into mesoderm tissues. MSCs were first described by Friedenstein et al. in the 1970s, as cells morphologically similar to fibroblasts and with a high ability to adhere to plastic surfaces [1]. MSC must express CD105, CD73 and CD90, and lack expression of CD45, CD34, CD14 or CD11b, CD79a or CD19 and HLA-DR surface molecules. Also, MSC must differentiate into osteoblasts, adipocytes and chondroblasts in vitro [2] [3].

Despite the suggested role in regenerative medicine as a broadly applicable stem cell source [4], there are mounting evidences of predominantly paracrine activity particularly in the setting of allogeneic hematopoietic stem cell transplantation where the beneficial effects have been shown on steroid resistant acute graft versus host disease (aGVHD) [5]-[7], on enhancing HSC engraftment [8]-[10], on conditioning regimen damaged tissue repair [11], and on bone marrow stromal repair [12].

MSC can be readily expanded and purified ex vivo from adipose and bone marrow mononuclear cells obtained from animals and humans [13]-[16], and also MSC can be isolated and expanded by bone marrow discharged bags and filters left over after the hematopoietic stem cell transplant [17]. In humans, the best known source of mesenchymal stem cells is the bone marrow [18], but it has also been isolated from other organs and tissues, such as skeletal muscle and dermis [19], adipose tissue [16], synovium [20], umbilical vein endothelium [21] and saphenous vein [22], kidney [23], umbilical cord blood and placenta [24] [25], cartilage [26], ligamentt [27] and lung [28].

Clinical grade MSC expansion is usually obtained by using fetal bovine serum (FBS) supplemented medium [29] with its potential safety hazards. It has shown the presence of FBS antibodies in humans after lymphocyte infusions [30] [31]. Furthermore, the World Health Organization (WHO) has published its concerns about xenoreactions following the infusion of bovine products in clinical practice [32]. In a recent study, the utilization of the platelets lysates (PL) has showed a protective effect on the MSCs chromosomal instability, when compared to FBS supplemented medium [33], further favoring human products to prepare culture cell for therapy.

Based on this, several groups are exploiting the expansion potential of human derived products obtained from PL [13] [34]-[37]. While the optimal number of cells to be infused is a problem not yet solved, it has been defined empirically for clinical efficacy that for clinical efficacy it required deliver to recipient $2 \times 10^{6} \mathrm{MSC} / \mathrm{Kg}$ [6], making it essential to find a safe method to obtain enough cells in the shortest period of time. We describe here our experience in ex vivo expansion of PL supplemented MSC, compare its expanding potential to that obtained with FBS supplementation, and test different culture cell densities to obtain clinical grade MSC cultures in the shorter period of time.

\section{Materials and Methods}

\subsection{Bone Marrow Donors}

Healthy bone marrow donors for HSCT were invited to participate and their residual cells were utilized after written informed consent.

After written informed consent, discharged bags and filters of BM aspirates were obtained from six healthy hematopoietic stem cell donors (median age 23.5 years). Total nucleated cells (TNC) were isolated by elution with saline ( $\mathrm{NaCl} 0.9 \%$, Baxter, SP, Brazil) of the residual cells left over in the bags and $200 \mu \mathrm{m}$ filters after the infusion of whole Bone Marrow (BM) explants for HSCT [17]. The obtained cells were then placed in conical tubes (Falcon, Becton, Dickinson and Company, CA, USA), centrifuged and the pellet was resuspended in a complete culture medium supplemented with FBS or PL plated at density of 300,000 nucleated cells $/ \mathrm{cm}^{2}$.

\subsection{Platelets Lysates Preparation}

PL preparation was based on the method described elsewhere [35]. In short, platelets concentrate bags from 6 donors were obtained from the Hospital de Clinicas de Porto Alegre Blood Bank immediately before their discharge time. The bags were frozen at $-80^{\circ} \mathrm{C}$ overnight and thawed at $37^{\circ} \mathrm{C}$ in the next day. This procedure was repeated for five times. Next, the lysed product was centrifuged at $3220 \mathrm{~g}$, for 30 minutes, four times and the supernatant filtered through a $0.22 \mu \mathrm{m}$ filter and heparinized. The final product was stored at $-20^{\circ} \mathrm{C}$ for up to 3 
months.

\subsection{Culture Medium}

Dulbecco's modified Eagle's medium (DMEM) (Gibco, Invitrogen corp., Carlsbad, CA, USA) was prepared with $1 \%$ penicillin G (100 U/ml) and streptomycin $(100 \mu \mathrm{g} / \mathrm{ml}$; Gibco) and supplemented with either $10 \%$ of FBS or PL.

\subsection{Cells and MSCs Cultures}

TNC were directly plated in duplicates with FBS or PL medium, at concentration of 300,000 cell/ $\mathrm{cm}^{2}$. The adherent cells were trypsinized and counted at seven days of culture, irrespective of the confluence percentage. In another set of experiments, the first adherent cells layer, either expanded in the presence of PL or FBS, was detached with Trypsin/EDTA (Invitrogen, USA) after obtaining $80 \%$ of confluence. After the first passage, the eluted cells were plated in the same medium as before, at concentration of $2000\left(1 \times 10^{4} / \mathrm{ml}\right), 3000(1.5 \times$ $\left.10^{4} / \mathrm{ml}\right), 4000\left(2 \times 10^{4} / \mathrm{ml}\right), 5000\left(2.5 \times 10^{4} / \mathrm{ml}\right), 6000\left(3 \times 10^{4} / \mathrm{ml}\right)$ and $7000\left(3.5 \times 10^{4} / \mathrm{ml}\right) \mathrm{cells} / \mathrm{cm}^{2}$, and the number of days to reach $80 \%$ of confluence was recorded. MSC viability was evaluated by Trypan Blue staining.

\subsection{Flow Cytometry Analysis}

Cultured cells were stained with CD105 PE, CD45 FITC, CD73 PE, CD14 FITC, CD90 PE, HLA-DR FITC, CD29 PE, CD34 PE (Becton, Dickinson and Company, USA), assayed in flow cytometer (FACSCalibur, Becton Dickinson) and the data analyzed with Paint-A-Gate program.

After detached the cells, the viability was determined and adjusted the concentration for $2 \times 10^{6} \mathrm{cell} / \mathrm{mL}$ in PBS, and then the cells were distributed in flow cytometry tubes (50 $\mu \mathrm{L} /$ tube). In which tube, $5 \mathrm{uL}-10 \mathrm{uL}$ of antibodies (according to the manufacturer's recommendations for the optimal volume of antibody to be used) were added in the appropriate combinations: CD105 PE, CD45 FITC, CD73 PE, CD14 FITC, CD90 PE, HLADR FITC, CD29 PE, and CD34 PE (Becton, Dickinson and Company, USA) for $50 \mu \mathrm{L}$ of cell suspension. The cells were incubating for $30 \mathrm{~min}$ at $4^{\circ} \mathrm{C}$, protected from light and $1 \mathrm{~mL}$ of PBS were added. After that, the cells were centrifuged at $1.200 \mathrm{rpm}$ for $10 \mathrm{~min}$ and removed the supernatant to eliminate unbound antibodies and then the cells were resuspended in $0.5 \mathrm{~mL}$ PBS. The cells were assayed in a flow cytometer (FACSCalibur, Becton Dickinson) and the data analyzed with Paint-A-Gate program.

\subsection{Differentiation Assay}

At the end of cell culture, the cells obtained from all sets of experiments were tested for osteogenic, adipogenic and chondrogenic differentiation. Osteogenic differentiation was induced in Dulbecco's modified Eagle's medium low glucose (DMEN Low) (Gibco, Invitrogen Corp., USA), FBS (Gibco, Invitrogen Corp., USA), ascorbic acid (0.2 mmol/L) (Acros Organics, Belgium), $\beta$-glycerophosphate (10 mmol/L) (Sigma, Germany) and dexamethasone $(0.1 \mu \mathrm{mol} / \mathrm{L})$, (Hypofarma, Brasil) for 30 days. Adipogenic differentiations were induced in Iscove's Modified Dulbecco's IMDM (Gibco, Invitrogen, USA) supplemented with 20\% platelets poor human plasma, heparin (5.000 UI/ml) (Eurofarma, Brasil), indomethacin (0.2 mmol/L) (Merck Sharp \& Dohme, USA) dexamethasone $(0.1 \mu \mathrm{mol} / \mathrm{L})$, and insulin $(10 \mu \mathrm{mol} / \mathrm{L})$ (Eli Lilly, Mexico). Chondrogenic differentiation was induced in DMEM Low supplemented with insulin (Cellofarm, Brazil), ascorbic acid and TGF- $\beta$ (Invitrogen, USA). Osteogenic, adipogenic and chondrogenic differentiation was stained by Alizarin Red staining (Sigma, Germany), Oil Red (Sigma, Germany), and Alcian Blue (Sigma, Germany)), respectively, as previously described [38].

\subsection{Statistical Analysis}

Results are presented as arithmetic median and standard error. Differences between PL and FBS cultures were analyzed by Student-T test and the time to obtain $80 \%$ of adherence in each cell concentration was tested by Generalized Estimating Equations. Differences were considered significant for $\mathrm{p}<0.05$. Statistical analysis was performed with software SPSS 18.0. 
The study was approved by the Ethics Committee at the Hospital de Clínicas de Porto Alegre under the number 08-601 and conducted at the Center for Cell Technology and Culture of the Experimental Research Center at the same hospital, under Good Manufactuting Practices (GMP) conditions.

\section{Results}

TNC were isolated from the washouts of discharged bags and filters of whole BM explants infusion utilized for HSCT from 6 different donors. The median age of donors was 23.5 years. The Table 1 summarizes information from these donors.

\subsection{Expansion of MSC in PL and FBS Medium}

The minimum number of platelets from which PL obtained was $5.5 \times 10^{10}$. As showed in Table 2, in PL supplemented medium the cell expansion was 3.75-fold higher than the expansion observed in FBS medium ( $\mathrm{p}=$ 0.005).

\subsection{Plating Cell Density}

A higher plating concentration $\left(3.5 \times 10^{4} / \mathrm{mL}\right)$ was more efficient to obtain $80 \%$ of confluence in the shorter time (6 days), when compared to $1.0,1.5$ or $2.0 \times 10^{4} / \mathrm{mL}$ ( 7.55 to 8.55 days) $\mathrm{p}=0.005$ (Table 3). As expected,

Table 1. Main characteristics from donors of filter and bags of whole BM explants infusion.

\begin{tabular}{ccc}
\hline Donor & Sex & Age \\
\hline MSC01BF & Male & 26 \\
MSC02BF & Female & 20 \\
MSC03BF & Female & 14 \\
MSC04BF & Male & 44 \\
MSC05BF & Male & 57 \\
MSC06BF & Female & 21 \\
\hline
\end{tabular}

Table 2. Comparison of cell expansion in PL and FBS supplemented medium in seven days of culture (plating cell density of 5000 cells $\left./ \mathrm{cm}^{2}\left(2.5 \times 10^{4} / \mathrm{ml}\right)\right)$.

\begin{tabular}{cccc}
\hline Supplement & PL & FBS & p \\
\hline Mean expansion (Standard error) & $11.88(4.08)$ & $2.5(1.06)$ & $0.005^{*}$ \\
\hline
\end{tabular}

Table 3. Number of days to obtain $80 \%$ of confluence and cell plating density in $10 \%$ PL or FBS supplemented medium.

\begin{tabular}{ccc}
\hline cell/ml & PL median days to confluence $\left(\mathrm{SD}^{* * *}\right)$ & FBS median days to confluence $\left(\mathrm{SD}^{* * *}\right)$ \\
\hline $1 \times 10^{4}$ & $8.55(2.07)$ & $13.91(3.30)$ \\
$1.5 \times 10^{4}$ & $8.00(2.10)$ & $13.00(3.63)$ \\
$2 \times 10^{4}$ & $7.55(1.97)$ & $12.45^{*}(3.45)$ \\
$2.5 \times 10^{4}$ & $7.09^{*}(1.97)$ & $12.27^{*}(3.55)$ \\
$3 \times 10^{4}$ & $6.55^{*}(1.29)$ & $11.55^{*}(3.45)$ \\
$3.5 \times 10^{4}$ & $6.00^{*}(1.41)$ & $11.27^{*}(2.90)$ \\
\hline
\end{tabular}

PL: $10 \%$ PL supplemented DMEM medium; FBS: $10 \%$ FBS supplemented DMEM medium; ${ }^{*} \mathrm{p}<0.05$. ${ }^{* *}$ SD: standard deviation. 
in FBS supplemented medium the time to reach $80 \%$ of confluence was longer when compared to PL medium (p $=0.005$ ). Interestingly, with FBS there was no significant difference in plating density of $2.0 \times 10^{4} \mathrm{cell} / \mathrm{ml}$ or more, only a density lower than that was significantly less efficient $(\mathrm{p}=0.005)$ (Table 3$)$.

\subsection{Clinical Grade MCS Expansion from the Washouts of Discharged Bags and Filters Left over from BM Infusion Utilized for HSCT}

In the presence of $10 \% \mathrm{PL}$, with plating density of 5000 nucleated cells $/ \mathrm{cm}^{2}\left(2.5 \times 10^{4} / \mathrm{ml}\right)$ we were able to consistently obtain clinical grade number of cells at the third passage (Figure 1), with at least two logs of expansion $\left(10 \times 10^{9}\right.$ or $10 \times 10^{11}$ cells) more than enough for the treatment of a $70 \mathrm{~kg}$ patient with cell therapy. The mean time from mononuclear cells plating to $\mathrm{P} 3$ was 35 days.

\subsection{Quality Control of Expanded MSC}

Osteogenic (Figure 2(a)), adipogenic (Figure 2(b)) and chondrogenic (Figure 2(c)) differentiation was obtained in all cultured conditions at the end of the third passage.

All cell products irrespective of the culture medium were $>90 \%$ CD105, CD73, CD90 and CD29 positive and negative for CD45, CD14, HLA-DR and CD34.

\section{Discussion}

Here we show that PL is significantly more efficient $(\mathrm{p}=0.05)$ than FBS supplemented medium for the ex vivo expansion of BM MSC. Our results are in accordance to Blande et al. [35], for adipocyte derived MSC, and Schallmoser et al. for BM derived MSC. The latter group suggested that the utilization of platelets bags from 10 donors yielded more consistent results than the utilization of individual donors [39]. Yet, another study exploited further this issue showing that there is a variability amongst different platelet donors and that PL expansion po-

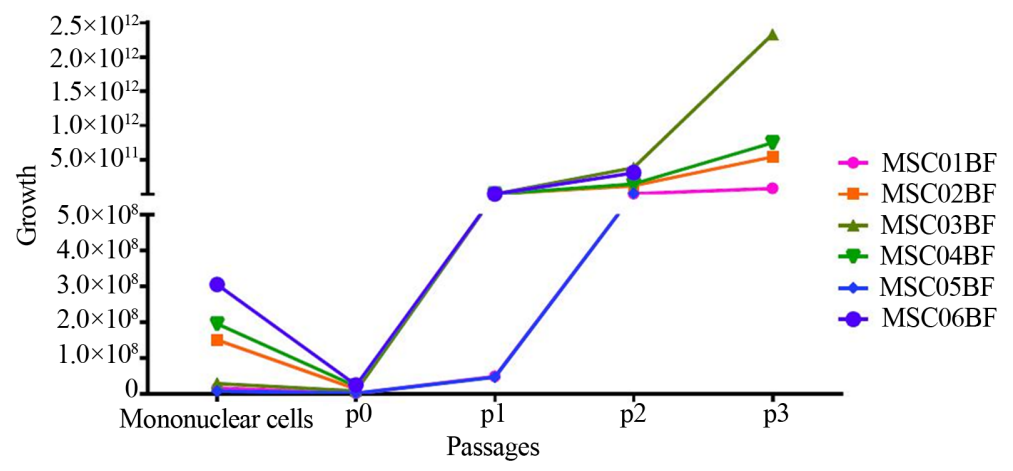

Figure 1. Cell growth according to the culture passages: Expansion of cell culture removed from filter and bag until P3, when a total of cells obtained ranged from $10 \times 10^{9}$ to $10 \times 10^{11}$ cells.

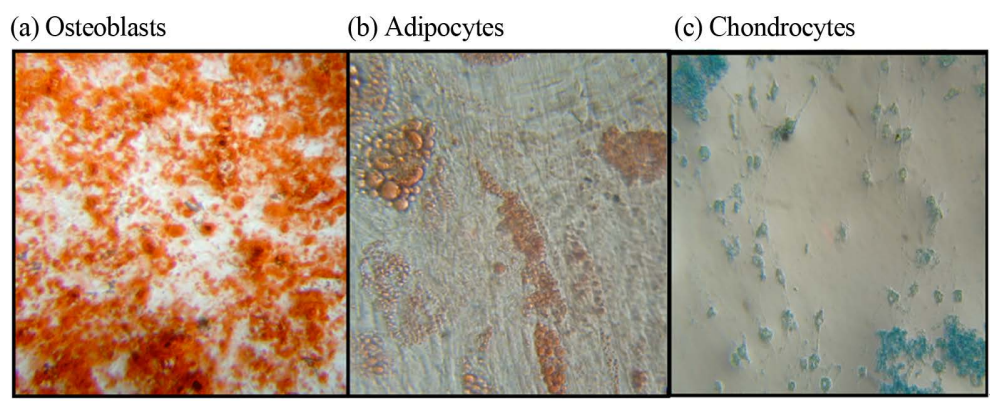

Figure 2. Plasticity of MSC grown under our conditions was shown by differrentiation into (a) adipocytes (in oil red O staining), (b) osteoblasts (in alizarin red staining) and (c) chondrocytes (in alcian blue staning). 
tential is correlated with the concentration of platelet derived growth factor and to lesser extent to the number platelets from which the PL was prepared [40]. Both studies pointed to the importance of the amount of protein and growth factors in the PL preparation. Perez-Ilzarbe and col., on the other hand, failed to show a significant difference on expansion potential between FBS and PL enriched or not with basic Fibroblast Growth Factor (bFGF) [41]. In our study, PL from 6 different donors, which is the average number of donors utilized in pool platelets concentrates for clinical application, was significantly superior to FBS $(p=0.005)$ for BM MSC expansion. Our results were reproducible irrespectively of the PL lot utilized (data not shown).

Third party MSC infusion for cellular therapy is acceptable and it has been shown in vitro that pooling of MSC from several donors generate higher and more stable immune suppression [42]. However, MSC have shown to be permissive to viruses [43] [44]. In the HSCT setting, the receptor is already subjected to unknown infections or to a possible chromosomal abnormality carried by the HSC donor [45] [46] since HSCT is a life saving procedure these are considered unavoidable collateral risks. The ideal scenario for in vitro expanded MSC therapy would be to obtain MSC from the same HSC donor, thus minimizing additional risks. There are, however, practical implications for that. The main obstacle is to obtain BM MSC from unrelated donors particularly when the HSC comes from a different institution, city or country. Washouts of discarded bone marrow collection and filters can be an alternative as it has been shown by us and others [17] to yield a high number of MSC, particularly when expanded in a PL enriched medium. A second obstacle is being able to obtain enough number of cells in a short period of time. Here we showed that plating 2.5 to $3.5 \times 10^{4} \mathrm{cell} / \mathrm{ml}$ in a PL supplemented medium significantly diminishes $(p=0.005)$ the time to obtain $80 \%$ confluence and hence speed up the passages while, as has been also shown by others [42], plating fewer cells concentration yields a higher number of cells. The former plating density could be utilized for first infusion while the latter would be for the following.

Sundin and cols. noted that the use of TNC from washouts bone marrow discharged bags and filters was not sufficient to obtain enough cells grown in the presence of 10\% FBS [47]. Capelli and col [48] comparing $10 \%$ FBS with 5\% PL concluded PL to be superior in obtaining a higher number of cells although in P5/6. In our study utilizing $10 \%$ PL we were able to obtain clinical grade number of cells in a shorter period of time (P2/3) Figure 1.

\section{Conclusion}

In conclusion, here we showed that the utilization of $10 \%$ PL is superior to $10 \% \mathrm{FBS}$, and that it's also superior to obtaining MSC from washouts bone marrow discharged bags and filters for the proliferation of clinical grade donor MSC to be utilized for therapy in the HSCT setting.

\section{Acknowledgements}

The study received financial support from the Research and Event Incentive Fund of Hospital de Clínicas de Porto Alegre (FIPE-HCPA) and The National Council for Scientific and Technological Development (CNPq).

\section{References}

[1] Amorin, B., Alegretti, A.P., Valim, V., Pezzi, A., Silva, M.A., Sehn, F. and Silla, L. (2013) Characteristics of Mesenchymal Stem Cells under Hypoxia. CellBio, 2, 9. http://dx.doi.org/10.4236/cellbio.2013.21002

[2] Dominici, M., Le Blanc, K., Mueller, I., Slaper-Cortenbach, I., Marini, F., Krause, D., Deans, R., Keating, A., Prockop, D. and E. Horwitz, (2006) Minimal Criteria for Defining Multipotent Mesenchymal Stromal Cells. The International Society for Cellular Therapy Position Statement. Cytotherapy, 8, 315-317. http://dx.doi.org/10.1080/14653240600855905

[3] Harichandan, A. and Buhring, H.J. (2011) Prospective Isolation of Human MSC. Best Practice \& Research Clinical Haematology, 24, 25-36. http://dx.doi.org/10.1016/j.beha.2011.01.001

[4] Caplan, A.I. and Bruder, S.P. (2001) Mesenchymal Stem Cells: Building Blocks for Molecular Medicine in the 21st Century. Trends in Molecular Medicine, 7, 259-264. http://dx.doi.org/10.1016/S1471-4914(01)02016-0

[5] Kebriaei, P., Isola, L., Bahceci, E., Holland, K., Rowley, S., McGuirk, J., Devetten, M., Jansen, J., Herzig, R., Schuster, M., Monroy, R. andUberti, J. (2009) Adult Human Mesenchymal Stem Cells Added to Corticosteroid Therapy for the Treatment of Acute Graft-Versus-Host Disease. Biology of Blood and Marrow Transplantation, 15, 804-811. http://dx.doi.org/10.1016/j.bbmt.2008.03.012

[6] Le Blanc, K., Frassoni, F., Ball, L., Locatelli, F., Roelofs, H., Lewis, I., Lanino, E., Sundberg, B., Bernardo, M.E., 
Remberger, M., Dini, G., Egeler, R.M., Bacigalupo, A., Fibbe, W. and Ringden, O. (2008) Mesenchymal Stem Cells for Treatment of Steroid-Resistant, Severe, Acute Graft-Versus-Host Disease: A Phase II Study. Lancet, 371, 15791586. http://dx.doi.org/10.1016/S0140-6736(08)60690-X

[7] Ringden, O. and Le Blanc, K. (2011) Mesenchymal Stem Cells for Treatment of Acute and Chronic Graft-Versus-Host Disease, Tissue Toxicity and Hemorrhages. Best Practice \& Research Clinical Haematology, 24, 65-72. http://dx.doi.org/10.1016/j.beha.2011.01.003

[8] Fouillard, L., Chapel, A., Bories, D., Bouchet, S., Costa, J.M., Rouard, H., Herve, P., Gourmelon, P., Thierry, D., Lopez, M. and Gorin, N.C. (2007) Infusion of Allogeneic-Related HLA Mismatched Mesenchymal Stem Cells for the Treatment of Incomplete Engraftment Following Autologous Haematopoietic Stem Cell Transplantation. Leukemia, 21, 568-570. http://dx.doi.org/10.1038/sj.leu.2404550

[9] Le Blanc, K., Samuelsson, H., Gustafsson, B., Remberger, M., Sundberg, B., Arvidson, J., Ljungman, P., Lonnies, H., Nava, S. and Ringden, O. (2007) Transplantation of Mesenchymal Stem Cells to Enhance Engraftment of Hematopoietic Stem Cells. Leukemia, 21, 1733-1738. http://dx.doi.org/10.1038/sj.leu.2404777

[10] Macmillan, M.L., Blazar, B.R., DeFor, T.E. and Wagner, J.E. (2009) Transplantation of Ex-Vivo Culture-Expanded Parental Haploidentical Mesenchymal Stem Cells to Promote Engraftment in Pediatric Recipients of Unrelated Donor Umbilical Cord Blood: Results of a Phase I-II Clinical Trial. Bone Marrow Transplantation, 43, 447-454. http://dx.doi.org/10.1038/bmt.2008.348

[11] Ringdén, O., Uzunel, M., Sundberg, B., Lönnies, L., Nava, S., Gustafsson, J., Henningsohn, L. and Le Blanc, K. (2007) Tissue Repair Using Allogeneic Mesenchymal Stem Cells for Hemorrhagic Cystitis, Pneumomediastinum and Perforated Colon. Leukemia, 21, 2271-2276.

[12] Fouillard, L., Bensidhoum, M., Bories, D., Bonte, H., Lopez, M., Moseley, A.M., Smith, A., Lesage, S., Beaujean, F., Thierry, D., Gourmelon, P., Najman, A. and Gorin, N.C. (2003) Engraftment of Allogeneic Mesenchymal Stem Cells in the Bone Marrow of a Patient with Severe Idiopathic Aplastic Anemia Improves Stroma. Leukemia, 17, 474-476. http://dx.doi.org/10.1038/sj.leu.2402786

[13] Bruder, S.P., Jaiswal, N. and Haynesworth, S.E. (1997) Growth Kinetics, Self-Renewal, and the Osteogenic Potential of Purified Human Mesenchymal Stem Cells during Extensive Subcultivation and Following Cryopreservation. Journal of Cellular Biochemistry, 64, 278-294. http://dx.doi.org/10.1002/(SICI)1097-4644(199702)64:2<278::AID-JCB11>3.0.CO;2-F

[14] Caplan, A.I. (2007) Adult Mesenchymal Stem Cells for Tissue Engineering versus Regenerative Medicine. Journal of Cellular Physiology, 213, 341-347. http://dx.doi.org/10.1002/jcp.21200

[15] Owen, M. (1988) Marrow Stromal Stem Cells. Journal of Cell Science Supplement, 10, 63-76. http://dx.doi.org/10.1242/jcs.1988.Supplement_10.5

[16] Zuk, P.A., Zhu, M., Mizuno, H., Huang, J., Futrell, J.W., Katz, A.J., Benhaim, P., Lorenz, H.P. and Hedrick, M.H. (2001) Multilineage Cells from Human Adipose Tissue: Implications for Cell-Based Therapies. Tissue Engineering, 7, 211-228. http://dx.doi.org/10.1089/107632701300062859

[17] Capelli, C., Salvade, A., Pedrini, O., Barbui, V., Gotti, E., Borleri, G., Cabiati, B., Belotti, D., Perseghin, P., Bellavita, P., Biondi, A., Biagi, E., Rambaldi, A., Golay, J. and Introna, M. (2009) The Washouts of Discarded Bone Marrow Collection Bags and Filters Are a Very Abundant Source of hMSCs. Cytotherapy, 11, 403-413. http://dx.doi.org/10.1080/14653240902960437

[18] Ahrens, N., Tormin, A., Paulus, M., Roosterman, D., Salama, A., Krenn, V., Neumann, U. and Scheding, S. (2004) Mesenchymal Stem Cell Content of Human Vertebral Bone Marrow. Transplantation, 78, 925-929. http://dx.doi.org/10.1097/01.TP.0000133305.81823.2A

[19] Young, H.E., Steele, T.A., Bray, R.A., Hudson, J., Floyd, J.A., Hawkins, K., Thomas, K., Austin, T., Edwards, C., Cuzzourt, J., Duenzl, M., Lucas, P.A. and Black Jr., A.C. (2001) Human Reserve Pluripotent Mesenchymal Stem Cells Are Present in the Connective Tissues of Skeletal Muscle and Dermis Derived from Fetal, Adult, and Geriatric Donors. The Anatomical Record, 264, 51-62. http://dx.doi.org/10.1002/ar.1128

[20] De Bari, C., Dell'Accio, F., Tylzanowski, P. and Luyten, F.P. (2001) Multipotent Mesenchymal Stem Cells from Adult Human Synovial Membrane. Arthritis \& Rheumatology, 44, 1928-1942. http://dx.doi.org/10.1002/1529-0131(200108)44:8<1928::AID-ART331>3.0.CO;2-P

[21] Covas, D.T., Siufi, J.L., Silva, A.R. and Orellana, M.D. (2003) Isolation and Culture of Umbilical Vein Mesenchymal Stem Cells. Brazilian Journal of Medical and Biological Research, 36, 1179-1183. http://dx.doi.org/10.1590/S0100-879X2003000900006

[22] Covas, D.T., Piccinato, C.E., Orellana, M.D., Siufi, J.L., Silva Jr., W.A., Proto-Siqueira, R., Rizzatti, E.G., Neder, L., Silva, A.R., Rocha, V. and Zago, M.A. (2005) Mesenchymal Stem Cells Can Be Obtained From the Human Saphena vein. Experimental Cell Research, 309, 340-344. http://dx.doi.org/10.1016/j.yexcr.2005.06.005

[23] Almeida-Porada, G., Shabrawy, D.E., Porada, C. and Zanjani, E.D. (2002) Differentiative Potential of Human Meta- 
nephric Mesenchymal Cells. Experimental Hematology, 30, 1454-1462.

http://dx.doi.org/10.1016/S0301-472X(02)00967-0

[24] Lee, M.W., Choi, J., Yang, M.S., Moon, Y.J., Park, J.S., Kim, H.C. and Kim, Y.J. (2004) Mesenchymal Stem Cells from Cryopreserved Human Umbilical Cord Blood. Biochemical and Biophysical Research Communications, 320, 273-278. http://dx.doi.org/10.1016/j.bbrc.2004.04.206

[25] Lee, O.K., Kuo, T.K., Chen, W.M., Lee, K.D., Hsieh, S.L. and Chen, T.H. (2004) Isolation of Multipotent Mesenchymal Stem Cells from Umbilical Cord Blood. Blood, 103, 1669-1675. http://dx.doi.org/10.1182/blood-2003-05-1670

[26] Alsalameh, S., Amin, R., Gemba, T. and Lotz, M. (2004) Identification of Mesenchymal Progenitor Cells in Normal and Osteoarthritic Human Articular Cartilage. Arthritis \& Rheumatism, 50, 1522-1532.

http://dx.doi.org/10.1002/art.20269

[27] Seo, B.M., Miura, M., Gronthos, S., Bartold, P.M., Batouli, S., Brahim, J., Young, M., Robey, P.G., Wang, C.Y.and Shi, S. (2004) Investigation of Multipotent Postnatal Stem Cells from Human Periodontal Ligament. The Lancet, 364, 149-155. http://dx.doi.org/10.1016/S0140-6736(04)16627-0

[28] Sabatini, F., Petecchia, L., Tavian, M., de Villeroche, V.J., Rossi, G.A. and Brouty-Boye, D. (2005) Human Bronchial Fibroblasts Exhibit a Mesenchymal Stem Cell Phenotype and Multilineage Differentiating Potentialities. Laboratory Investigation, 85, 962-971. http://dx.doi.org/10.1038/labinvest.3700300

[29] Grisendi, G., Anneren, C., Cafarelli, L., Sternieri, R., Veronesi, E., Cervo, G.L., Luminari, S., Maur, M., Frassoldati, A., Palazzi, G., Otsuru, S., Bambi, F., Paolucci, P., Pierfranco, C., Horwitz, E. and Dominici, M. (2010) GMP-Manufactured Density Gradient Media for Optimized Mesenchymal Stromal/Stem Cell Isolation and Expansion. Cytotherapy, 12, 466-477. http://dx.doi.org/10.3109/14653241003649510

[30] Selvaggi, T.A., Walker, R.E. and Fleisher, T.A. (1997) Development of Antibodies to Fetal Calf Serum with Arthus-Like Reactions in Human Immunodeficiency Virus-Infected Patients Given Syngeneic Lymphocyte Infusions. Blood, 89, 776-779.

[31] Sundin, M., Ringden, O., Sundberg, B., Nava, S., Gotherstrom, C. and Blanc, K.L. (2007) No Alloantibodies against Mesenchymal Stromal Cells, but Presence of Anti-Fetal Calf Serum Antibodies, after Transplantation in Allogeneic Hematopoietic Stem Cell Recipients. Haematologica, 92, 1208-1215. http://dx.doi.org/10.3324/haematol.11446

[32] WHO (1997) Medicinal and Other Products and Human and Animal Transmissible Spongiform Encephalopathies: Memorandum from a WHO Meeting. Bulletin of the World Health Organization, 75, 505-513.

[33] Crespo-Diaz, R., Behfar, A., Butler, G.W., Padley, D.J., Sarr, M.G., Bartunek, J., Dietz, A.B. and Terzic, A. (2010) Platelet Lysate Consisting of a Natural Repair Proteome Supports Human Mesenchymal Stem Cell Proliferation and Chromosomal Stability. Cell Transplant, 20, 797-811.

[34] Bernardo, M.E., Avanzini, M.A., Perotti, C., Cometa, A.M., Moretta, A., Lenta, E., Del Fante, C., Novara, F., de Silvestri, A., Amendola, G., Zuffardi, O., Maccario, R. and Locatelli, F. (2007) Optimization of In vitro Expansion of Human Multipotent Mesenchymal Stromal Cells for Cell-Therapy Approaches: Further Insights in the Search for a Fetal Calf Serum Substitute. Journal of Cellular Physiology, 211, 121-130. http://dx.doi.org/10.1002/jcp.20911

[35] Blande, I.S., Bassaneze, V., Lavini-Ramos, C., Fae, K.C., Kalil, J., Miyakawa, A.A., Schettert, I.T. and Krieger, J.E. (2009) Adipose Tissue Mesenchymal Stem Cell Expansion in Animal Serum-Free Medium Supplemented with Autologous Human Platelet Lysate. Transfusion, 49, 2680-2685. http://dx.doi.org/10.1111/j.1537-2995.2009.02346.x

[36] Carrancio, S., Lopez-Holgado, N., Sanchez-Guijo, F.M., Villaron, E., Barbado, V., Tabera, S., Diez-Campelo, M., Blanco, J., Miguel, J.F.S. and Del Canizo, M.C. (2008) Optimization of Mesenchymal Stem Cell Expansion Procedures by Cell Separation and Culture Conditions Modification. Experimental Hematology, 36, 1014-1021. http://dx.doi.org/10.1016/j.exphem.2008.03.012

[37] Muller, I., Kordowich, S., Holzwarth, C., Spano, C., Isensee, G., Staiber, A., Viebahn, S., Gieseke, F., Langer, H., Gawaz, M.P. Horwitz, E.M., Conte, P., Handgretinger, R. and Dominici, M. (2006) Animal Serum-Free Culture Conditions for Isolation and Expansion of Multipotent Mesenchymal Stromal Cells from Human BM. Cytotherapy, 8, 437-444. http://dx.doi.org/10.1080/14653240600920782

[38] Beyer, N.N. and da Silva M.L. (2006) Mesenchymal Stem Cells: Isolation, In vitro Expansion and Characterization. Handbook of Experimental pharmacology, 174, 249-282.

[39] Schallmoser, K., Bartmann, C., Rohde, E., Reinisch, A., Kashofer, K., Stadelmeyer, E., Drexler, C., Lanzer, G., Linkesch, W. and Strunk, D. (2007)Human Platelet Lysate Can Replace Fetal Bovine Serum for Clinical-Scale Expansion of Functional Mesenchymal Stromal Cells. Transfusion, 47, 1436-1446. http://dx.doi.org/10.1111/j.1537-2995.2007.01220.x

[40] Horn, P., Bokermann, G., Cholewa, D., Bork, S., Walenda, T., Koch, C., Drescher, W., Hutschenreuther, G., Zenke, M., Ho, A.D. and Wagner, W. (2010) Impact of Individual Platelet Lysates on Isolation and Growth of Human Mesenchymal Stromal Cells. Cytotherapy, 12, 888-898. http://dx.doi.org/10.3109/14653249.2010.501788 
[41] Perez-Ilzarbe, M., Diez-Campelo, M., Aranda, P., Tabera, S., Lopez, T., del Canizo, C., Merino, J., Moreno, C., Andreu, E.J., Prosper, F. and Perez-Simon, J.A. (2009) Comparison of Ex vivo Expansion Culture Conditions of Mesenchymal Stem Cells for Human Cell Therapy. Transfusion, 49, 1901-1910. http://dx.doi.org/10.1111/j.1537-2995.2009.02226.x

[42] Samuelsson, H., Ringden, O., Lonnies, H. and Blanc, K.L. (2009) Optimizing In vitro Conditions for Immunomodulation and Expansion of Mesenchymal Stromal Cells. Cytotherapy, 11, 129-136. http://dx.doi.org/10.1080/14653240802684194

[43] Sundin, M., Lindblom, A., Orvell, C., Barrett, A.J., Sundberg, B., Watz, E., Wikman, A., Broliden, K. and Blanc, K.L. (2008) Persistence of Human Parvovirus B19 in Multipotent Mesenchymal Stromal Cells Expressing the Erythrocyte P Antigen: Implications for Transplantation. Biology of Blood and Marrow Transplantation, 14, 1172-1179. http://dx.doi.org/10.1016/j.bbmt.2008.08.003

[44] Sundin, M., Orvell, C., Rasmusson, I., Sundberg, B., Ringden, O. and Blanc, K.L. (2006) Mesenchymal Stem Cells Are Susceptible to Human Herpesviruses, but Viral DNA Cannot Be Detected in the Healthy Seropositive Individual. Bone Marrow Transplant, 37, 1051-1059. http://dx.doi.org/10.1038/sj.bmt.1705368

[45] Hertenstein, B., Hambach, L., Bacigalupo, A., Schmitz, N., McCann, S., Slavin, S., Gratwohl, A., Ferrant, A., Elmaagacli, A., Schwertfeger, R., Locasciulli, A., Zander, A., Bornhauser, M., Niederwieser, D. and Ruutu, T. (2005) Development of Leukemia in Donor Cells after Allogeneic Stem Cell Transplantation-A Survey of the European Group for Blood and Marrow Transplantation (EBMT). Haematologica, 90, 969-975.

[46] Reichard, K.K., Zhang, Q.Y., Sanchez, L., Hozier, J., Viswanatha, D. and Foucar, K. (2006) Acute Myeloid Leukemia of Donor Origin after Allogeneic Bone Marrow Transplantation for Precursor T-Cell Acute Lymphoblastic Leukemia: Case Report and Review of the Literature. American Journal of Hematology, 81, 178-185. http://dx.doi.org/10.1002/ajh.20389

[47] Sundin, M., Remberger, M., Lonnies, H., Sundberg, B., Ringden, O. and Blanc, K.L. (2008) No Increased Trapping of Multipotent Mesenchymal Stromal Cells in Bone Marrow Filters Compared with Other Bone Marrow Cells. Cytotherapy, 10, 238-242. http://dx.doi.org/10.1080/14653240801965164

[48] Capelli, C., Domenghini, M., Borleri, G., Bellavita, P., Poma, R., Carobbio, A., Mico, C., Rambaldi, A., Golay, J. and Introna, M. (2007) Human Platelet Lysate Allows Expansion and Clinical Grade Production of Mesenchymal Stromal Cells from Small Samples Of Bone Marrow Aspirates or Marrow Filter Washouts. Bone Marrow Transplant, 40, 785-791. http://dx.doi.org/10.1038/sj.bmt.1705798 